\title{
The Evolution of Measurement Methods of Comparative Advantage and New Trends in Intra- Product International Specialization ${ }^{2}$
}

\begin{abstract}
Lijun Jia
Maoguo Wu

Yixuan Liu

SHU-UTS SILC Business School, Shanghai University, Jiading District, Shanghai, People's Republic of China

doi: 10.19044/esj.2016.v12n7p82 URL:http://dx.doi.org/10.19044/esj.2016.v12n7p82

Abstract

In the development and the evolution of international trade theory, comparative advantage has always been a core concept. A great deal of research pertains to the calculation methods of comparative advantage. However, most previous research on measurement methods of comparative advantage is mainly based on a country's import/export volume of a specific industry or product. Under the circumstances of contemporary intra-product international specialization, previous measurement methods are not appropriate. It is imperative to improve original measure methods of comparative advantage through stripping overseas contents of exports, and putting forward a new measurement index reflecting the domestic contents of export.
\end{abstract}

Keywords: International Trade; Comparative Advantage; Intra-Product Specialization; Non-Competitive Input-Output Model

\section{Introduction}

In the development and evolution of international trade theory, comparative advantage (CA) has always been a core concept. Since Ricardo's (1817) classic model of comparative advantage in trade was put forward, the theory of comparative advantage has been gathered to form a theory system. An approach of comparative advantage calculation through almost two centuries' development. The most widely used application has

\footnotetext{
2 This research is funded by The Humanities and Social Science Youth Fund Project of the Ministry of Education of People's Republic of China (2012, Project No. 12YJC790074)
} 
been proposed after the Revealed Comparative Advantage (RCA) and its modification put forward by Balassa (1965). RCA index has a significant characteristic, that is, indirectly calculating a nation or an industry's aggregated comparative advantage from the results of total export and import trade. In the index, the variables are easy to find and strongly operable, which play an important role in a long time.

However, the reality is that the international division is gradually intensified from inter-industry and intra-industry division to intra-product. The comparative advantage of a country or region cannot be calculated from cost of production or labor productivity merely. The calculation of the status and the ability for value added on industry chains or product procedure is very important. Therefore, the traditional calculation on comparative advantage has its limitations to some extent and trade advantage by means of traditional comparative advantage index will have bias with the precise situation. That means the total volume of export will be immediately divided into the domestic contents and the overseas contents for the exported goods, and the comparative advantage calculation by means of trade value added will be utilized to re-calculate the domestic foreign trade CA. That will, in theory, adapt to the real situation of international division being intensified to intra-product division. In practice, it is not only beneficial to interpret the source of different nations' value added in the intra-product international division and the CA, but also provide a new idea for domestic industry upgrading path and the transferring way of foreign trade development through selecting the industry with potential competitive power as the future focused industry for cultivation.

This paper first summarizes and reviews different calculation methods of CA. It then proposes a new CA calculation method including domestic contents in a nation's export in the background of intra-product international division. This paper extends existing literature by synthesizing previous literature and proposing a new tool of investigating CA of foreign trade taking into account of domestic industry.

\section{Literature Review}

The calculation based on labor productivity was put forward by the economists in favor of classic comparative advantage, Ricardo (1817) as the representative, such as relative labor productivity index, relative cost index, opportunity cost index and improved CP index (Stolper, Samuerson, 1941) and CATM index. However, the calculation method based on labor productivity is based on the hypothesis that only one factor of production exists, which is so much different from the real situation. In addition, for most nations and products, those indexes are difficult to collect. Accordingly, those indexes interpret the problems relating to CA in theory 
very well. The scholars focus more on the analysis of theory with regard to the indexes' application (Amita Batra,2007; Toshihiro Okubo, 2011; Kozo Kiyota,2011), but less on the empirical calculation.

In the real world, trade not only reflects the difference on labor productivity in each nation, but also reflects the difference on resources in each nation. Heckscher (1919) and Ohlin (1933) raised the model of Resource Endowment. They believed that each nation had the different distribution of factors of production and that a nation has CA in the industries where abundant resources are intensively used. Heckscher (1919) raised the theory that the kind of factor intensity is judged by $\mathrm{K} / \mathrm{L}$, the ratio of capital-labor input.

As discussed above, no matter the calculation method based on labor productivity or the method based on the resource endowment, they have limited application because of difficulty in data collection or limitations of calculation function. Since the data of trade volume on import/export is easy to obtain, Balassa (1965) raised the Revealed Comparative Advantage Index (RCA) based on the total volume of export/import. Subsequently, many scholars made improvements and modification on it based on the data of total volume of export/import. Thus, the application of it becomes wide.

From the RCA indexes and formulate, they have an apparent feature that a nation or an industry's whole CA is indirectly calculated through the total volume of product's export and import trade. Thus, they have some limitations listed below. Firstly, the trade statistics are calculated with total amount. The intermediate and final goods are both included. Therefore, the official value of trade is exaggerated because of the repeated calculation for the intermediaries. In addition, the indexes are the source of calculation based on the after-trade statistics. According to the traditional trade theory, CA mainly includes the relative price before trade. The after-trade statistics utilization will be subject to various policies' distortion in the process of transaction and the statistics cannot reflect the real price level before trade. Moreover, when an industry's trade division mode is dominated by intraindustry or intra-product trade rather than the inter-industry trade, the industry CA calculated by RCA indexes is not objective and it could not predict a nation's trade mode for development.

Another approach to modify the RCA indexes puts forward new calculation index based on the statistics of export and import. For instance, Lafay (1992) raised the LFI index and he also took the bidirectional trade flows of export and import into consideration, which could solve the problem of the distorted calculation results due to the fluctuation on export and import's prices well. Additionally, through the introduction of the weights of trade share, the products in different categories can be compared and sequenced. 
The differences of the CA in different provinces in China are calculated. The conclusion is drawn that the top ten provinces indeed had strong CA in labor-intensive industry. Therefore, most of the provinces in China indeed realize the production optimization in accordance with CA.

The CA indexes are calculated in different industries. The result is shown that part of the agricultural products, some resource-related products, labor-intensive products have CA in China. In the capital-intensive products, technology-intensive products, some service industries, they basically have no CA.

According to different nations, based on the calculation of trade CA in the nations of different categories and the comparison with the situation in China, the complementarities and competitiveness of China and other nations are studied. Also, the overseas scholars calculate the explicit CA in different nations and different industries by means of the indexes such as Abidin, Mahan, Zainal; Loke, WaiHeng, 2008, Marconi, Daniela, 2012 and the like.

\section{Evolution of Measurement Methods of Comparative Advantage Relative Labor Productivity Index}

Ricardo (1817) raised the theory of comparative advantage on labor productivity. He believed that, the difference on international labor productivity was the only decisive factor for trade CA in a nation and a nation exported the products with relatively high labor productivity. He then raised the theory of calculating a nation's CA using relative labor productivity, relative cost and opportunity cost, which are called relative labor productivity indexes. The indexes’ formulae are listed below.

Product A's Relative Labor Productivity (RP) =

$$
\begin{aligned}
& \text { Product A's Labor Productivity }\left(\mathrm{Q}_{\mathrm{A} / \mathrm{L}}\right) \\
& \text { Product B's Labor Productivity }\left(\mathrm{Q}_{\mathrm{B} / \mathrm{L}}\right) \\
& \text { Product } \mathrm{A}^{\prime} \text { s Relative Cost }(\mathrm{RC})=
\end{aligned}
$$

Product $A^{\prime} s$ Unit Labor Factor Input $\left(a_{L A}\right)$

Product $B^{\prime}$ s Unit Labor Factor Input $\left(\mathrm{a}_{\mathrm{LB}}\right)$

Product $\mathrm{A}^{\prime} \mathrm{s}$ Opportunity Cost $(\mathrm{OC})=$

$\frac{\text { Product } \mathrm{B}^{\prime} \text { s Output Decrease }\left(\Delta \mathrm{Q}_{\mathrm{B}}\right)}{\text { Product } \mathrm{A}^{\prime} \text { s Output Increase }\left(\left(\Delta \mathrm{Q}_{\mathrm{A}}\right)\right)}$

Those indexes are based on nation $\mathrm{H}$ and $\mathrm{F}$, two products $\mathrm{A}$ and $\mathrm{B}$ and a factor of production (Labor L). Q stands for the product' quantity, $\mathrm{a}_{\mathrm{j}}$ stands for the labor quantity of producing unit product output. If $\mathrm{RP}^{\mathrm{H}}>\mathrm{RP}^{\mathrm{F}}$, $\mathrm{RC}^{\mathrm{H}}<\mathrm{RC}^{\mathrm{F}}, \mathrm{OC}^{\mathrm{H}}<\mathrm{OC}^{\mathrm{F}}$, nation $\mathrm{H}$ has comparative advantage of producing product A compared with nation $\mathrm{F}$.

Because the main theories of those indexes are based on Ricardo's Comparative Advantage Theory, the theory has two main characteristics. Firstly, labor is the only factor of production and other factors such as 
capital, technology, resources are not considered. The nation difference on labor productivity is exogenous and unchangeable. In addition, the theory simply identifies the CA through the comparison with two products' relative cost or labor productivity. For various products, the original indexes are difficult to identify, and even the conclusion drawn from the theory can be overthrown.

\section{CP and CATM Index}

Because of the drawbacks mentioned above, the Class Comparative Advantage has been extended in two aspects. On one hand, set the indexes for making comparison invarious nations, two products and one factor of production (Stolper, Samuelsson, 1941), which is called CP index. The Formula (4) shows it below.

$$
\frac{\mathrm{C}_{\mathrm{A}}}{\mathrm{C}_{\mathrm{B}}}<\frac{\mathrm{P}_{\mathrm{A}}}{\mathrm{P}_{\mathrm{B}}}
$$

$\mathrm{P}$ stands for the product's international price. For any nation, when Formula (4) is met, it means that the nation has CA to produce product A. Therefore, product A should be exported and product B should be imported. However, international price has close relation with exchange rate, which is artificially influenced. The CA for a country, thus, cannot be calculated accurately.

On the other hand, some scholars expanded the indexes of Class Advantage to the comparison in two nations and various products, and CATM (Comparative Advantage of Two Countries with Multi-production) is the representative. The CATM believed that, for the product $\mathrm{i}$, if $\mathrm{W}^{\mathrm{H}}{ }_{*} \mathrm{a}^{\mathrm{H}}{ }_{\mathrm{i}}<$ $\mathrm{W}^{\mathrm{F}} * \mathrm{a}_{\mathrm{i}}{ }^{\mathrm{F}}$, namely $\mathrm{a}^{\mathrm{H}}{ }_{\mathrm{i}} / \mathrm{a}_{\mathrm{i}}{ }^{\mathrm{F}}<\mathrm{W}^{\mathrm{F}} / \mathrm{W}^{\mathrm{H}}$, then the cost for producing $\mathrm{i}$ in nation $\mathrm{H}$ is relatively low, given $\mathrm{CA}$. $\mathrm{W}^{\mathrm{H}}, \mathrm{W}^{\mathrm{F}}$ are domestic wage rate and foreign domestic wage rate respectively.

However, the model above has apparent drawbacks. Firstly, the hypothesis for single factor of production is very different from the real situation. Secondly, in the real application, we are more concerned about whether a nation, compared with other countries, has CA. Wang Fuzhong, Zhu Lili (2006) made improvements on CATM approach from two aspects. Firstly, the single factor of production was expanded into a variety of factors of production. Secondly, the concepts of two nations in the model were expanded into broader scope, and the CA of domestic main products of agriculture was calculated using the approach.

\section{The Calculation Method Based on Resource Endowment}

$$
\text { Ratio of capital }- \text { labor input }=\frac{\text { The volumn of capital input } \mathrm{K}}{\text { The volumn of labor input L }}
$$


Based on the index and a nation or region's resources, if two products $A$ and $B$ met the following condition $\frac{K_{A}}{L_{A}}>\frac{K_{B}}{L_{B}}$, then a nation with abundant capital has $\mathrm{CA}$ in producing product $\mathrm{A}$. On the contrary, labor-intensive country has CA in producing product B.

Ohlin used LII index (the index of labor intensity, like Formula (6)) to expand $\mathrm{K} / \mathrm{L}$ into the use of various products.

$$
\text { Index of Labor Intensity }\left(\mathrm{LII}_{\mathrm{j}}\right)=\frac{\mathrm{K}_{\mathrm{j}} / \mathrm{L}_{\mathrm{j}}}{\mathrm{K}_{\mathrm{t}} / \mathrm{L}_{\mathrm{t}}}
$$

where, $\mathrm{Kj}$ and $\mathrm{Lj}$ are j product's capital and labor input, $\mathrm{Kt}$ and $\mathrm{Lt}$ are all the products' capital and labor input in the nation. If LIIj is higher, product $\mathrm{j}$ has higher capital intensity and a nation with relatively abundant capital has CA in producing product $\mathrm{j}$. LII index is more comprehensive than the index of ratio of capital-labor input and it does not have restriction on the comparison with two products. However, LII index is difficult for statistics and real operation.

Domestic Resource Cost (DRC) makes the relation between domestic resources and exchange rates to calculate a nation's CA. The index was put forward by Professor Pearson the beginning of 1970s. DRC refers to the opportunity cost of domestic resources requiring input when making a production on the condition of earning or saving one unit marginal foreign exchange. If DRC divided by the official exchange rate $\mathrm{E}$ equals a coefficient, then the coefficient is called Domestic Resource Cost Coefficient (DRCC). Formula (7) is listed below.

$$
\operatorname{DRCC}_{\mathrm{j}}=\frac{\mathrm{DRC}_{\mathrm{j}}}{\mathrm{E}}
$$

In reality, DRCC can be viewed as the average efficiency transferred from domestic resource to exchange rate in the process of production. However, DRC method has some drawbacks. Firstly, full materials on opportunity cost and average price should be considered when one calculates the index. Because of the material limitations, in reality, those factors are difficult to calculate. Therefore, the scholars often replace the opportunity cost with the explicit factors in it and replace average price with the market equilibrium price. The estimated calculation inevitably influences the accuracy of results. Secondly, the method needs to consider the factor exchange rate. If the exchange rate is distorted, DRCC number may be overestimated or underestimated. As a result, all or most of the products' production in a nation will have comparative advantage or comparative disadvantage. The result is not true. Accordingly, in recent years, most scholars have mainly focused on discussing the contribution's degree the 
resources can have to a nation's CA (Thomas Gunton,2003; Coen N. Teulings,2005; Grancay, Martin,2012).

\section{RCA Index and Its Simple Modification}

RCA index describes the performance of relative export of each industry (product group) in a quantitative way. It reveals the CA in a nation's international trade and makes up for the disadvantages of classical or neoclassical calculation indexes. The principle of calculation is shown in equation (8) below.

$$
R C A 1_{i j}=\text { BRCA }_{i j}=\frac{x_{i j}}{\sum_{j} x_{i}} / \frac{x_{w j}}{\sum_{j} x_{w}}
$$

where, $\mathrm{X}$ stands for volume of export, i stands for nation, $\mathrm{j}$ stands for products and $\mathrm{w}$ stands for the collection of nations referred (can also be the world or a region).If $R C A 1_{i j}>2.5$, then the product $\mathrm{j}$ in nation $\mathrm{i}$ has very strong CA. If $1.25 \leqq R C A 1_{i j} \leqq 2.5$, then the product $\mathrm{j}$ in nation $\mathrm{i}$ has strong CA. If $0.8 \leqq R C A 1_{i j} \leqq 1.25$, then the product $\mathrm{j}$ in nation $\mathrm{i}$ has $\mathrm{CA}$ in middle level. If RCA $1<0.8$, the product $\mathrm{j}$ in nation $\mathrm{i}$ has weak CA. The index has been examined by many scholars (Yeats, 1985; Balance, Forstner and Murray, 1987; Vollrath, 1991). Many scholars (Donges and Riedel, 1977; Balassa, 1979; UNIDO, 1982; Marchese and De Simone, 1989; Bender, 2002 et al) utilized the index when calculating trade CA.

Subsequently, the scholars made improvements of the index. Firstly, the index is simply modified for calculating the complementarities of trade advantage among nations. It makes up for the RCA1's one-sidedness. Vallarta (1991) considered a nation's import data and RCA1 was modified to obtain RCA2 shown in equation (9).

$$
R C A 2_{i j}=R X A_{i j}-R_{i j}=\frac{x_{i j}}{\sum_{j} x_{i}} / \frac{x_{w j}}{\sum_{j} x_{w}}-\frac{m_{i j}}{\sum_{j} m_{i}} / \frac{m_{w j}}{\sum_{j} m_{w}}
$$

where $\mathrm{m}$ is import, RXA (Relative Export Advantage), RMA (Relative Import Advantage) stand for relative export advantage and relative import advantage respectively. The index makes up for the fact that RCA1 only considers the export, but does not consider the import. If $R C A 2_{i j}>0$, nation i has explicit CA for product $\mathrm{j}$.

Neven (1995) uses the difference between the export proportion of product $\mathrm{j}$ in nation $\mathrm{i}$ and the import proportion of it (share balance of net trade) for the product's CA with equation (10) shown below.

$$
\operatorname{RCA}_{\mathrm{ij}}=\frac{\mathrm{x}_{\mathrm{ij}}}{\sum_{\mathrm{j}} \mathrm{x}_{\mathrm{i}}}-\frac{\mathrm{m}_{\mathrm{ij}}}{\sum_{\mathrm{j}} \mathrm{m}_{\mathrm{i}}}
$$

Dimelis and Gatsios (1995), Guel and Martin (1995) and Westin (1998) obtained the Formula (11) RCEA4 with the modification of RCA3. The trade CA of Eastern Europe and Western Europe is calculated with RCA4. 


$$
\mathrm{RCA}_{i j}=\operatorname{RCA}_{i j} / \frac{x_{i j}}{\sum_{j} x_{i}}+\frac{m_{i j}}{\sum_{j} m_{i}}=\left[\frac{x_{i j}}{\sum_{j} x_{i}}-\frac{m_{i j}}{\sum_{j} m_{i}}\right] /\left[\frac{x_{i j}}{\sum_{j} x_{i}}+\frac{m_{i j}}{\sum_{j} m_{i}}\right]
$$

In order to further calculate the trade mode, A.R.Hoen, J.Oosterhaven (2006) raised addictive RCA (ARCA) for modification. ARCA equals the difference between the proportion of export share for product $\mathrm{j}$ in nation $\mathrm{i}$ and the proportion of share for product $\mathrm{j}$ in nation referred. The equation of RCA5 is below.

$$
\begin{aligned}
& \operatorname{RCA}_{i j}=A_{\text {RCA }} \text { ij }= \\
& \frac{\mathrm{x}_{\mathrm{ij}}}{\sum_{\mathrm{j}} \mathrm{x}_{\mathrm{i}}}-\frac{\mathrm{x}_{\mathrm{wj}}}{\sum_{\mathrm{j}} \mathrm{x}_{\mathrm{W}}}
\end{aligned}
$$

If ARCA index $>0$, the nation $i$ has explicit CA compared with the collection of nations referred when producing product $\mathrm{j}$. If ARCA index $=0$, nation $\mathrm{i}$ has the perfect intra-industry trade mode with the nation referred to product $\mathrm{j}$. If $\mathrm{ARCA}=1$, it is the perfect inter-industry trade mode.

Run Yu (2009) et al. considered that the original RCA could only be compared between different periods and different nations and it could not reflect a nation's dynamic CA in the whole period. Accordingly, the Normalized RCA was raised to modify the original RCA. They pointed out that nations referred have neither comparative advantage nor comparative disadvantage, when previous RCAs index would be either 1 (for RCA1) or 0 (for other RCA indexes). Run Yu et al. viewed it as comparative-advantageneutral. They thought that when the CA was neutral, product $\mathrm{j}$ in the nation referred had the value of export $\hat{x}_{\mathrm{ij}}=\mathrm{x}_{\mathrm{i}} \mathrm{x}_{\mathrm{wj}} / \mathrm{x}_{\mathrm{w}}$. However, the real value of export was $\mathrm{x}_{\mathrm{ij}}$, and then $\Delta \mathrm{x}_{\mathrm{ij}}=\mathrm{x}_{\mathrm{ij}}-\hat{\mathrm{x}}_{\mathrm{ij}}=\mathrm{x}_{\mathrm{ij}}-\mathrm{x}_{\mathrm{i}} \mathrm{x}_{\mathrm{wj}} / \mathrm{x}_{\mathrm{w}}$, which is shown as RCA6 in Formula (13)

$$
\operatorname{RCA6}_{j}=\mathrm{NRCA}=\frac{\Delta \mathrm{x}_{\mathrm{ij}}}{\mathrm{x}_{\mathrm{w}}}=\frac{\mathrm{x}_{\mathrm{ij}}}{\mathrm{x}_{\mathrm{w}}}-\frac{\mathrm{x}_{\mathrm{i}} \mathrm{x}_{\mathrm{wj}}}{\mathrm{x}_{\mathrm{w}} \mathrm{x}_{\mathrm{w}}}
$$

If NRCA $>0$, then the nation referred has comparative advantage when producing product $\mathrm{j}$; if $\mathrm{NRCA}<0$, then it has comparative disadvantage.

Laursen (1998) considered that the original RCA did not have the symmetry and should be modified. Accordingly, the Symmetrical RCA is established.

$$
\mathrm{RCA}_{\mathrm{j}}=\mathrm{SRCA}=(\mathrm{BRCA}-1) /(\mathrm{BRCA}+1)
$$

Proudman and Redding (1998) raised that a product's CA in a nation by means of BRCA's arithmetic average could be calculated as WRCA, N standing for product's sort or quantity.

$$
\mathrm{RCA}_{\mathrm{j}}=\mathrm{WRCA}=\left(\mathrm{BRCA}_{\mathrm{j}}\right) /\left(\frac{1}{\mathrm{~N}} \sum_{\mathrm{j}=1}^{\mathrm{N}} \mathrm{BRCA}_{\mathrm{j}}\right)
$$




\section{The New Index Based on RCA}

The calculation formula of LFI index is in equation (16).

$$
\begin{gathered}
L^{L F} I_{i j}= \\
100 *\left[\frac{x_{i j}-m_{i j}}{x_{i j}+m_{i j}}-\frac{\sum_{j=1}^{N}\left(x_{i j}-m_{i j}\right)}{\sum_{j=1}^{N}\left(x_{i j}+m_{i j}\right)}\right] * \\
\frac{x_{i j}+m_{i j}}{\sum_{j=1}^{N}\left(x_{i j}+m_{i j}\right)}
\end{gathered}
$$

Other scholars raised that a nation's trade CA can be reflected by international percentage of occupancy, trade competition (TC) advantage and so forth. Among them, international percentage of occupancy refers to what a product's value of export in a nation in a certain period accounts for the product's value of export in the same period throughout the world. The index usually is utilized, together with other indexes, to analyze the status quo of foreign trade in a nation. The index of trade competition advantage refers to what the difference on export trade (have crossed the border) accounts for the total value of export and import.

\section{Further Research}

In the intra-industry international division, two problems should be concerned. The one is how to subtract the value formed overseas from the exported goods in a nation. The other one is to observe how much value goes into the final goods after the inputs are into the next-step production. Many scholars considered that the utilization of index of trade value added could solve those problems (Arndt,1998; Hummels,2001 ; Helpman,2006 ; Schott,2008 ; Koopman, Powers, Wang \&Wei, 2011 ; Noguera, Guillermo , 2012 et al). Different scholars used different methods when calculating the trade value added. There are mainly two characteristics summarized from those literatures. Firstly, the input-output method has been utilized generally when the trade value added is calculated. The data is from the competitive input-output table released in China. Secondly, the index of trade value added is utilized to calculate the benefit distribution of a nation involved in the international trade. However, the index fails to be combined with a nation's foreign trade CA calculation.

Sanyal and Jones (1982), Dixit and Grossman (1982), Falvey and Kierzkowski (1987) consider that comparative advantage is the decisive factor of vertical specialization or intra-product international division. The added value of domestic products reflects that in a nation's participation international intra-product division, how many final goods for import are produced domestically. The calculation of an industry's CA in a nation based on the index is more straightforward and practical. From them, the calculation method based on the trade value added in the article to re- 
calculate the CA in foreign trade is more adaptable for the new trends of intra-product international division.

In the perspective of micro-level, competitive advantages of firms also have relationship with factor intensity, which could benefit for lower costs and larger revenues. Firms prefer to export their production if they have production with competitive advantages, and decrease in tariffs could also raise the trend of export (Buono, 2009). In the circumstance of trade liberalization, firms with comparative advantage get more hurt because of decrease of trade costs. However, when every firms product both comparative-advantage production and comparative-disadvantage production, the influence of trade liberalization will be declined.

\section{Conclusion}

To sum up, there are two drawbacks in the calculation method based on labor productivity and resource endowment. Firstly, they are utilized based on the products, and it is difficult to extend to the industry. Secondly, the statistics related in the variables of each index are complicated and they are difficult to calculate. In addition, the indexes of salaries, exchange rate can be artificially influenced. Also, although the RCA, which is based on the total value of export/import has a very wide application for calculation, it is more used in inter-industry trade and it could not reflect the current status of industry chains or product procedures and ability for value added in the intraproduct international division. Accordingly, the improvements on the calculation method of foreign trade CA in the future intra-product international division should be observed.

Accordingly, in the intra-product international division, the calculation method of a nation's foreign trade can have breakthrough from two aspects. Firstly, breakthrough is made on the calculation method of trade value added. Previously, scholars utilized competitive input-output method to calculate the trade value added. The method requires many hypotheses to calculate the import-input coefficient in the production process. If the calculation of trade value added is directly based on non-competitive inputoutput method from import-input data. The result will be more scientific, accurate and practical. Secondly, index of trade value added can be utilized to make breakthrough for the calculation method of foreign trade CA. Previously, scholars utilized trade value added to calculate the gain from trade in a nation in most cases and few scholars calculated a nation's foreign trade CA based on the index. If the explicit RCA can be combined with it, the trade value added is utilized to modify the original index of total value of import and export, and the index of CA on trade value added is built to make the calculation. So the defects of RCA method will be overcome. Moreover, the real situation of the CA in a nation's foreign trade will be better reflected 
in the intra-product international division. Furthermore, if the modified trade CA index can be utilized to re-calculate the foreign trade CA in different industries in China, the calculation results of new and old indexes are compared and the potentially competitive industries are distinguished, the domestic trade structure will be optimized and the new ideas will be provided for transferring the domestic way of trade development.

\section{References:}

Amita Batra. 2007. "Structure of Comparative Advantage of China and India: Global and Regional Dynamics.” China \& World Economy, 15(6): 6986.

Asuyama, Yoko. 2012. "Skill Distribution and Comparative Advantage: A Comparison of China and India.” World Development, 40(5):956-969. Balassa, B. 1965. "Trade Liberalization and Revealed Comparative Advantage.” The Manchester School of Economic and Social Studies, 33: 99123.

Coen N. Teulings. 2005. "Comparative Advantage, Relative Wages, and the Accumulation of Human Capital.” Journal of Political Economy, 113(2): 425-461.

Costinot , Arnaud, Dave Donaldson, Jonathan Vogel and Ivan Werning. 2015. “Comparative Advantage and Optimal Trade Policy.” Quarterly Journal of Econimics, 130(2): 659-702

Deardorff, Alan V. 2014. "Local Comparative Advantage: Trade Costs and the Pattern of Trade” International Journal of Economic Theory . 10(1):9-35 Debaere, Peter. 2014. "The Global Economics of Water: Is Water a Source of Comparative Advantage?” American Economic Journal-Applied Econimics. 6(2):32-48

Grancay, Martin. 2012. "The Orgins of The Principle of Comparative Advantage and The Role of Agriculture.” Actual Problems of Economics, 136(2): 380-389.

Helpman, Elhanan, 2006. "Trade, FDI and the Organizations of Firm.” Journal of Economic Literature, 13: 589 630.

Helpman, Elhanan, 2013. Foreign Trade and Investment: Firm-Level Perspectives. Mimeo Harvard University.

Hoen AR and Oosterhaven J. 2006. "On the Measurement of Comparative Advantage.” Ann Reg Sci, 40: 677-691.

Hummels, D. 2001. “Toward a geography of trade costs. ” Purdue University Working paper 17.

Johnson R. C. and Noguera G. 2012. “Accounting for intermediates: Production sharing and trade in value added.” Journal of International Economics, 86(2): 224-236. 
Koopman, R., Powers, W., Wang, Z., \& Wei, S. J. 2010. “Give credit where credit is due: Tracing value added in global production chains.” National Bureau of Economic Research:No. w16426.

Kozo Kiyota. 2011. "A Test of the Law of Comparative Advantage.” Revisited Rev World Economy, 147: 771-778.

Licina, Derek. 2011. "Disaster Preparedness-Formalizing a Comparative Advantage for the Department of Defense in U.S. Global Health and Foreign Policy” Military Medicime, 176(11): 1207-1211. Marconi, Daniela. 2013. "Environmental Regulation and Revealed Comparative Advantages in Europe: Is China a Pollution Haven?” Review of International Economics, 20(3): 616-635.

Melitz, Marc and Stephen Redding. 2013. Firm Heterogeneity and Aggregate Welfare. Mimeo Harvard University.

Meoqui, Jorge Morales. 2011. "Comparative Advantage and the Labor Theory of Value." History of Political Economy, 43(3):743-763

Nishioka, Shuichiro. 2013. "R\&D, Trade in Intermediate Inputs, and the Comparative Advantage of Advanced Countries." Journal of the Japaness and International Economics,30:96-110 Otsuka, Keijiro. 2013. "Food Insecurity, Income Inequality, and the Changing Comparative Advantage in World Agriculture.” Agricultrual Econimics, 44(1):7-18.

Oberschachtsiek, Dirk. 2012. "The Experience of the Founder and Selfemployment Duration: a Comparative Advantage Approach.” Small Business Economics, 39(1):1-17

Steven, Brakman, Inklaar Robert and Van Marrewijk, Charles. 2013. "Structural Change in OECD Comparative Advantage." Journal of International Trade \& Economic Development , 22(6):817-838. Toshihiro Okubo. 2011. "Ricardian Comparative Advantage and Geographical Concentration.” Review of Development Economics, 15(4): 620-637.

Vis, Barbara. 2012. “The Comparative Advantages of QCA and Regression Analysis for Moderately Large-N Analyses.” Sociological Methods \& Research, 41(1):168-198. 